\title{
Effect of different processes on composition, properties and in vitro starch digestibility of grass pea flour
}

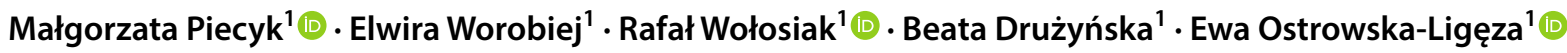

Received: 31 July 2018 / Accepted: 22 November 2018 / Published online: 27 November 2018

(c) The Author(s) 2018

\begin{abstract}
The objective of this study was to determine the effect of processes of seed disintegration and cooking and their order on digestibility of starch of grass pea seeds. Analyses were carried out in flour made of cooked grass pea seeds (CSF) and in flour made of raw ground seeds and subjected to identical treatments (CF). In addition, physicochemical properties of flour were determined to identify factors which affected starch digestibility. In CSF, analyses demonstrated decreased temperatures and enthalpy of transition and an increased range of transition temperatures. However, enthalpy value was still relatively high, probably as a result of starch retrogradation during drying. Compared to CF, the rate of starch hydrolysis in CSF was significantly lower and, as a consequence, the predicted glycemic index (pGI) was also significantly lower. The rate of CF starch hydrolysis and a high value of its pGI point to a highly significant effect of seeds disintegration before cooking, which resulted in complete gelatinization of starch during cooking. In contrast, incomplete gelatinization of starch during cooking and retrogradation of gelatinized starch during drying were observed in CSF. These changes caused slower starch hydrolysis, lower pGI, and significantly higher content of resistant starch in these flours compared to CF. Results obtained in study demonstrate that flour from cooked grass pea seeds may be used in food products to decrease their GI and to enrich them in resistant starch.
\end{abstract}

Keywords Grass pea $\cdot$ Starch digestibility $\cdot$ Cooked seed flour $\cdot$ Cooked flour

\section{Introduction}

Dried seeds of legumes are valuable sources of many nutrients including protein, starch, minerals, and vitamins [1]. In addition, they are rich in compounds displaying a high biological activity, i.e. dietary fiber including oligosaccharides and compounds with the antioxidative potential like, e.g., some polyphenolic compounds [2]. Ample epidemiological surveys point to a relationship between consumption of these seeds and reduced risk of development of selected metabolic diseases like diabetes or circulatory system diseases and neoplasms [3, 4]. For this reason, the UN General Assembly has declared the year 2016 an International Year of Pulses with the aim to increase world's population awareness regarding their health-promoting properties. Despite

Małgorzata Piecyk

malgorzata_piecyk@sggw.pl

1 Faculty of Food Sciences, Warsaw University of Life Sciences - SGGW, 159 Nowoursynowska Str., 02-787 Warsaw, Poland obvious benefits stemming from the intake of pulses, their use for culinary purposes in Europe is low, as their annual consumption reaches $2.7 \mathrm{~kg}$ per capita compared to the global average of $6.5 \mathrm{~kg}$ per capita [5]. This is partly due to their long preparation for consumption.

An especially valuable trait of legume seeds is slow digestion of starch, owing to the fact that they are rich in slowly-digestible starch (SDS) and, consequently, their glycemic index (GI) is low. The slow digestion of starch in these seeds is explained by the presence of intact tissue structures surrounding starch granules, a high content of highly viscous soluble fiber fraction, presence of digestibility-inhibiting compounds like, e.g., $\alpha$-amylase inhibitor, a high content of amylose, $\mathrm{C}$ type of starch crystallinity, as well as by stronger interactions between amylose chains [6]. Legume seeds contain also resistant starch (RS) defined as starch and products of its degradation which escape absorption in the small intestine of a normal man [7]. The presence of RS in a diet has a positive effect on humans as it contributes to stimulation of bacteria beneficial to human organism, an increase in SCFA content, $\mathrm{pH}$ reduction in the colon, reduction of a 
postprandial glucose level in blood, and a decrease in blood cholesterol level [8].

Increased incidence of type II diabetes has caused a growing interest in legume seeds which could be used for the production of functional food with a low glycemic index (GI), e.g. pasta or bread. Unfortunately, the expected effect is not always achieved. For example, Goni and Valentin-Gamazo [9] demonstrated that replacing part of wheat flour in spaghetti with chickpea caused a decrease in GI determined in vivo, whereas Marinangeli et al. [10] observed no significant changes in GI value after replacing wheat flour in pasta with flour made of whole pea seeds. A significant decrease of in vitro digestibility was, in turn, observed after replacing wheat flour in pasta by flour made of cooked and dried legume seeds [11].Various effects of legume flour addition on GI of obtained products is conditioned by many factors. It has been shown, that contents of SDS and RS in pulses depends on the species and variety of seeds, and environmental conditions during crop cultivation $[12,13]$. Literature data indicate that GI of legume flour may be lowered by an appropriate preparation of seeds. Slower digestion of starch was observed in flour from unhulled or hydrothermally-processed seeds [14-16].

In the world, grass pea (Lathyrus sativus L.) is mostly cultivated for stock-feed and only partly for human consumption. In Europe grass pea is one of the less common grain legumes. However, products prepared from those seeds are consumed in some regions of Spain, France, Germany, Bulgaria and Poland [17]. Likewise other legume seeds, grass pea seeds contain some components valuable in human nutrition, but also anti-nutrients, e.g. inhibitors of proteases, tannins, and neurotoxins including mainly $\beta-N$-oxalyl- $\alpha, \beta-$ diaminoproprionic acid ( $\beta$-ODAP), which may reduce seeds applicability, especially in the raw form $[18,19]$. The content of $\beta$-ODAP in grass pea cultivated in Europe is fairly low and reaches on average $0.847 \mathrm{mg} / \mathrm{g}$ seeds [17]. In addition, both soaking and cooking seeds reduces contents of neurotoxins even by $90 \%$ [20]. Starch of grass pea seeds grown in Poland has a high amylose content (38-39\%), exceeding that found in seeds of other Polish legumes [21], which may affect starch digestibility especially after cooking the seeds. Moreover, based on available literature, it can be concluded that the influence of processing on digestibility of grass pea starch was not examined in contrary to other legume starches.

Considering the above, the objective of this study was to determine the effect of processing design on composition and related to digestibility properties of starch of grass pea seeds. Analyses of starch digestibility were carried out in flour made of cooked and of cooked \& frozen grass pea seeds and in raw flour subjected to similar treatments. Analyses of the physicochemical properties of flour produced from processed seeds was conducted as well to identify factors which affected starch digestibility.

\section{Materials and methods}

\section{Materials}

The experimental material was seeds of grass pea (Lathyrus sativus) var. Derek and var. Krab, originating from the Plant Breeding and Seed Production Centre "Spójnia" in Nochów, Poland. To produce raw flour (RF), seeds were ground in a laboratory mill (IKA M20) and sieved through a screen with $125 \mu \mathrm{m}$ openings.

\section{Processing}

\section{Flour from processed seeds}

The seeds (200 g) were soaked in water (ratio of 1:3) for $16 \mathrm{~h}$ at room temperature, then water was decanted and the seeds were again poured with distilled water in a ratio of 1:5. Afterwards, the grass pea seeds were cooked in boiling water in open dish until they could be crushed with fingers: variety Derek for 40 and variety Krab for $60 \mathrm{~min}$. To produce flours from cooked seeds (CSF), moiety of the cooked seeds was dried in a vacuum dryer $\left(40{ }^{\circ} \mathrm{C}, 18 \mathrm{~h}, 60 \mathrm{mbar}\right)$, ground in a laboratory mill (IKA M20) and sieved through a screen with $125 \mu \mathrm{m}$ opening. Remaining from the same processing cooked seeds were packed in professional plastic bags, subjected to air freezing (natural convection, $-18{ }^{\circ} \mathrm{C}$ ) and stored at this temperature for 21 days. Afterwards, the seeds were subjected to convective thawing for $2 \mathrm{~h}$. Then flour from cooked and stored after freezing seeds (C\&FSF) was prepared as described for CSF.

Until chemical analyses, the preparation were stored in tightly closed plastic containers $\left(4{ }^{\circ} \mathrm{C}\right)$. In turn, analyses of digestibility were carried out immediately after seeds grinding.

\section{Processing of flour}

Analyses of starch digestibility were also carried in ground seeds (raw flours) subjected to similar treatments like whole seeds. The raw flour (100 $\mathrm{mg}$ ) and $2 \mathrm{~mL}$ water were added to screw glass centrifuge tubes, which were heated in a boiling water bath for $30 \mathrm{~min}$ (cooked flour-CF). Cooked \& frozen flour (C\&FF) was prepared in the first stage as cooked flour, then the samples were cooled for $1 \mathrm{~h}$ at room temperature and frozen in the aforementioned conditions $\left(-18^{\circ} \mathrm{C}, 21\right.$ days). Prior to starch digestibility determination the pastes were defrosted at room temperature for $2 \mathrm{~h}$. 


\section{Chemical composition of flour}

\section{Moisture, ash, protein and fat contents}

Moisture content was determined by gravimetry heating $\left(130{ }^{\circ} \mathrm{C}\right.$ for $2 \mathrm{~h}$ ), using $5 \mathrm{~g}$ of sample. Ash and total nitrogen contents were determined in accordance with AOAC method [22]. The percentage of crude protein was estimated by multiplying the total nitrogen content by 6.25 . Fat content was determined by extraction with hexane for $3 \mathrm{~h}$ using a Soxhlet apparatus according to the AOCS method [23].

\section{Total phenolics content (TPC)}

The amount of total phenolics in $70 \%$ acetone extracts was determined with the Folin-Ciocalteu's reagent [24]. Absorption at $700 \mathrm{~nm}$ was measured (Shimadzu UV-160A). The content of total phenolics was expressed as gallic acid (Sigma) equivalents in $\mathrm{mg} \mathrm{GAE} / 100 \mathrm{~g} \mathrm{dm}$.

\section{Total starch and amylose contents}

A total starch assay kit (Megazyme International, Ireland) was used to determine the starch content. Samples (100 mg) were pre-dissolved in $2 \mathrm{M} \mathrm{KOH}$ at $4{ }^{\circ} \mathrm{C}$ and $\mathrm{pH}$ was then adjusted with acetate buffer. Starch was hydrolysed (thermostable $\alpha$-amylase, amyloglucosidase) in a water bath at $50{ }^{\circ} \mathrm{C}$. Liberated glucose was analysed using the glucose oxidase-peroxidase assay kit (K-GLUC, Megazyme), and TS was calculated as glucose $\times 0.9$.

Apparent amylose content was determined using the method of Williams et al. [25]. A flour samples (20 mg db) were mixed with $10 \mathrm{~mL}$ of $0.5 \mathrm{M} \mathrm{KOH}$. The suspensions was well mixed and heated in water bath $\left(90^{\circ} \mathrm{C}, 15 \mathrm{~min}\right)$. The dissolved flour samples were then diluted to $100 \mathrm{~mL}$ with distilled water. $10 \mathrm{~mL}$ of solutions were transferred into $50 \mathrm{~mL}$ volumetric flasks and $5 \mathrm{~mL}$ of $0.1 \mathrm{M} \mathrm{HCl}$ and $0.5 \mathrm{~mL}$ of iodine reagent were added. The volumes were made up to $50 \mathrm{~mL}$ and the absorbance was measured at $625 \mathrm{~nm}$. The quantity of amylose was calculated from standard curve developed by using known concentration and ratio blends of amylose and amylopectin.

\section{Physicochemical properties}

\section{Differential scanning calorimetry (DSC)}

Gelatinization temperatures were measured and recorded on a differential scanning calorimeter (DSC, TA Instruments Q 200) equipped with a thermal analysis data station. Approximately $4.0 \mathrm{mg}$ of flour were weighed accurately into an aluminium pan. Water was added to obtain the ratio of dry matter: water as 1:3, and the pan was hermetically sealed and kept for $24 \mathrm{~h}$ at room temperature. The samples were heated from $20^{\circ} \mathrm{C}$ up to $110^{\circ} \mathrm{C}$ with the heating rate of $10^{\circ} \mathrm{C}$ per minute. The onset $\left(\mathrm{T}_{\mathrm{o}}\right)$, peak $\left(\mathrm{T}_{\mathrm{p}}\right)$, conclusion $\left(\mathrm{T}_{\mathrm{c}}\right)$ temperatures and the gelatinization enthalpy $(\Delta \mathrm{H})$ were estimated directly from the instrument software.

\section{Swelling power (SP) and amylose leaching (AML)}

The swelling power of raw and processed flours was determined as described by Leach et al. [26] with modification. Samples $(0.2 \mathrm{~g})$ were mixed with $10 \mathrm{~mL}$ of distilled water in centrifugal tubes. The suspensions were heated at 60, 70, 80 , and $90^{\circ} \mathrm{C}$ for $30 \mathrm{~min}$. The tubes were rapidly cooled and were then centrifuged at $1500 \mathrm{x} g$ for $10 \mathrm{~min}$. Supernatant was withdrawn and its part $(5 \mathrm{~mL})$ was dried at $110^{\circ} \mathrm{C}$ to a constant weight to quantify the soluble fraction. SP was represented as the ratio of the weight of wet sediment to the weight of initial dry sample deducting the amount of soluble components.

In obtained supernatants amylose content also was determined. Suitable quantity of supernatant $(0,2-3 \mathrm{~mL})$ was transferred into $50 \mathrm{~mL}$ volumetric flasks followed by the addition of stock iodine solution [25] and the volume made up to mark. The absorbance of solution was measured after $5 \mathrm{~min}(625 \mathrm{~nm})$. The amylose leaching (AML) was extrapolated from a standard absorbance-amylose content curve and was calculated as percentage of amylose leached per $100 \mathrm{~g}$ of dry starch.

\section{In vitro starch digestibility}

In vitro starch digestibility in samples (RF, CSF, C\&FSF, $\mathrm{CF}$ and $\mathrm{C} \& \mathrm{FF}$ ) was determined following the method described by Englyst et al. [7] with modifications of Chung et al. [27]. Briefly, samples were incubated with porcine pancreatin (P-7545, activity 8x USP/g, Sigma), amyloglucosidase (EC 3.2.1.3., $3300 \mathrm{U} / \mathrm{mL}$, Megazyme) and invertase (EC 3.2.1.26, $300 \mathrm{U} / \mathrm{mg}$; Megazyme) enzymes at $37^{\circ} \mathrm{C}$ for $180 \mathrm{~min}$. Aliquots $(0.1 \mathrm{~mL})$ were removed at 20, 30, 60, 90,120 and $180 \mathrm{~min}$ and mixed with $1 \mathrm{~mL}$ of $80 \%$ ethanol. Starch classifications based on the rate of hydrolysis were: rapidly digestible starch (digested within $20 \mathrm{~min}, \mathrm{RDS}$ ), slowly digestible starch (digested between 20 and $120 \mathrm{~min}$, SDS) and resistant starch (undigested after $120 \mathrm{~min}, \mathrm{RS}$ ). All values were corrected for free glucose (FG), which included the glucose part of sucrose. The free glucose was measured in a separate sample after the hydrolysis of sucrose with invertase. The amounts of glucose released from starch and FG were measured by the glucose oxidase-peroxidase assay kit (K-GLUC, Megazyme). The predicted glycemic index of the samples was estimated according to the equation described by Granfeld et al. [28]: pGI $=8.198+0.862 \cdot \mathrm{HI}$. The hydrolysis index (HI) was calculated as the area under 
the hydrolysis curve (0-180 min) obtained for the sample, expressed as a percentage of the corresponding area for white bread. A non-linear model established by Goni et al. [29] was applied to describe the kinetics of starch hydrolysis.

\section{Statistical analysis}

All analyses were performed in three independent subsamples (one replication each) with the exception of DSC analysis, which was performed in two sub-samples. Results were expressed as means and standard deviations and were subjected to a statistical analysis (Statistica v. 10.0 software). The significance of differences between means was estimated with post hoc Duncan test at $\mathrm{p} \leq 0.05$.

\section{Results and discussion}

\section{Chemical composition of flour from raw and processed seeds}

The RFs had a similar content of starch, but contents of ash, fat, proteins, and polyphenols differed slightly between the varieties (Table 1). Contents of protein and ash determined in our study are consistent with literature data concerning seeds of grass pea grown in Poland, whereas fat content is higher $[19,30]$. Cooking caused an increase in contents of starch and protein, by ca. 17\% (Derek) and 5\% (Krab) in CSF as a result of losses of some components, which is confirmed by decreased contents of ash by 33\% (Derek) and 35\% (Krab), fat by 55\% (Derek) and 69\% (Krab), and polyphenols by $8 \%$ (Derek) and 28\% (Krab). Also components not determined in our study like e.g. saccharose, oligosaccharides or soluble dietary fiber, may migrate to water [31]. The above discussed changes in the composition of legume seeds after processing are in agreement with our previous studies $[14,32]$.

The C\&FSF from both grass pea varieties had lower contents of ash and polyphenols compared to CSF. The C\&FSF from seeds of Krab var. was additionally characterized by an increased content of starch, which may result from a decreased protein content noted for this variety. Losses of components in seeds dried after cooking and freezing may be due to their small leaching during thawing.

The content of apparent amylose in flours made of native seeds reached ca. $10 \%$ and was consistent with amylose content range provided in literature for various legume seeds, i.e. 9-16\% [33]. In flours from cooked and dried seeds, amylose content decreased by ca. $25 \%$. Similar changes in amylose content after cooking various legume seeds were observed by Piecyk et al. [14, 34]. However, a study on amylose leaching from raw flours heated in water to $90{ }^{\circ} \mathrm{C}$, conducted by Chung et al. [33], indicate a significantly higher solubility of this component than in our study, which was probably due to the damage of cell walls during seed milling and to easier penetration of water to starch granules in flours during their heating.

\section{Thermal characteristic of raw and processed flour}

Thermal properties of starch, its gelatinization temperature in particular, reflect the perfection of starch crystallites. Flour is a multi-component system whose thermal properties are affected by the presence of not only starch, but also the second main component-proteins. The analysis of parameters describing starch gelatinization in raw flour revealed no significant differences between the studied flours (Table 2). Onset $\left(T_{o}\right)$, peak $\left(T_{p}\right)$, conclusion $\left(T_{c}\right)$ temperatures and gelatinization enthalpy in flours from seeds of Krab and Derek cultivars reached 65.8 and $66.2{ }^{\circ} \mathrm{C}, 71.6$ and $72.9^{\circ} \mathrm{C}, 81.3$ and $82.6{ }^{\circ} \mathrm{C}$ as well as 4.3 and $4.1 \mathrm{~J} / \mathrm{g}$,

Table 1 Chemical composition of flour from raw and processed grass pea seeds

\begin{tabular}{|c|c|c|c|c|c|c|c|}
\hline Flour & Moisture (\%) & Ash (\% dm) & Protein $(\% \mathrm{dm})$ & Fat $(\% \mathrm{dm})$ & $\begin{array}{l}\text { Total phenolics (mg } \\
\text { GAE } / 100 \mathrm{~g} \mathrm{dm})\end{array}$ & Starch $(\% \mathrm{dm})$ & Amylose $(\% \mathrm{dm})$ \\
\hline \multicolumn{8}{|l|}{ Derek } \\
\hline $\mathrm{RF}$ & $11.7 \pm 0.0^{\mathrm{b}}$ & $3.06 \pm 0.02^{\mathrm{d}}$ & $29.0 \pm 0.3^{\mathrm{b}}$ & $1.2 \pm 0.1^{\mathrm{c}}$ & $120.9 \pm 0.6^{\mathrm{d}}$ & $49.7 \pm 0.2^{\mathrm{a}}$ & $10.1 \pm 0.2^{\mathrm{e}}$ \\
\hline CSF & $16.2 \pm 0.0^{\mathrm{e}}$ & $1.97 \pm 0.01^{\mathrm{b}}$ & $30.6 \pm 0.1^{\mathrm{cd}}$ & $0.5 \pm 0.1^{\mathrm{ab}}$ & $111.0 \pm 2.0^{c}$ & $58.6 \pm 0.7^{\mathrm{bc}}$ & $7.8 \pm 0.1^{\mathrm{a}}$ \\
\hline C\&FSF & $16.2 \pm 0.0^{\mathrm{e}}$ & $1.83 \pm 0.01^{\mathrm{a}}$ & $30.5 \pm 0.3^{c}$ & $0.7 \pm 0.0^{\mathrm{b}}$ & $84.2 \pm 1.1^{\mathrm{a}}$ & $58.8 \pm 0.6^{\mathrm{bc}}$ & $8.6 \pm 0.1^{\mathrm{d}}$ \\
\hline \multicolumn{8}{|l|}{ Krab } \\
\hline RF & $11.5 \pm 0.0^{\mathrm{a}}$ & $2.87 \pm 0.07^{\mathrm{c}}$ & $28.6 \pm 0.3^{\mathrm{a}}$ & $1.6 \pm 0.1^{\mathrm{d}}$ & $135.4 \pm 1.0^{\mathrm{e}}$ & $49.9 \pm 0.2^{\mathrm{a}}$ & $10.9 \pm 0.2^{\mathrm{f}}$ \\
\hline CSF & $15.2 \pm 0.0^{\mathrm{d}}$ & $1.92 \pm 0.05^{\mathrm{b}}$ & $30.1 \pm 0.2^{\mathrm{c}}$ & $0.5 \pm 0.2^{\mathrm{ab}}$ & $97.2 \pm 1.3^{\mathrm{b}}$ & $57.8 \pm 0.5^{\mathrm{b}}$ & $8.1 \pm 0.0^{\mathrm{b}}$ \\
\hline C\&FSF & $14.9 \pm 0.0^{\mathrm{c}}$ & $1.82 \pm 0.04^{\mathrm{a}}$ & $28.9 \pm 0.0^{\mathrm{ab}}$ & $0.4 \pm 0.1^{\mathrm{a}}$ & $86.6 \pm 1.9^{\mathrm{a}}$ & $59.0 \pm 1.0^{\mathrm{c}}$ & $8.3 \pm 0.0^{\mathrm{c}}$ \\
\hline
\end{tabular}

Data with the same superscript alphabets in columns are not significantly different $(\mathrm{p}<0.05)$

Values are mean $\pm \mathrm{SD}, \mathrm{n}=3$

$R F$ Raw flour, $C S F$ cooked seed flour, $C \& F S F$ cooked \& frozen seed flour 
Table 2 Thermal properties of flour from raw and processed grass pea seeds

\begin{tabular}{|c|c|c|c|c|c|}
\hline \multirow[b]{2}{*}{ Flour } & \multicolumn{5}{|c|}{ Gelatinization } \\
\hline & $\mathrm{T}_{\mathrm{o}}\left({ }^{\circ} \mathrm{C}\right)$ & $\mathrm{T}_{\mathrm{p}}\left({ }^{\circ} \mathrm{C}\right)$ & $\mathrm{T}_{\mathrm{c}}\left({ }^{\circ} \mathrm{C}\right)$ & $\Delta \mathrm{H}(\mathrm{J} / \mathrm{g})$ & $\begin{array}{l}\mathrm{T}_{\mathrm{c}}-\mathrm{T}_{\mathrm{o}} \\
\left({ }^{\circ} \mathrm{C}\right)\end{array}$ \\
\hline \multicolumn{6}{|l|}{ Derek } \\
\hline $\mathrm{RF}$ & $65.8 \pm 1.5^{\mathrm{c}}$ & $71.6 \pm 0.2^{\mathrm{b}}$ & $81.3 \pm 0.3^{\mathrm{d}}$ & $4.3 \pm 0.6^{\mathrm{ab}}$ & $15.5 \pm 1.8^{\mathrm{a}}$ \\
\hline $\mathrm{CSF}$ & $47.4 \pm 1.2^{\mathrm{a}}$ & $59.9 \pm 1.1^{\mathrm{a}}$ & $75.5 \pm 0.5^{\mathrm{c}}$ & $3.7 \pm 0.4^{\mathrm{a}}$ & $28.1 \pm 1.7^{\mathrm{c}}$ \\
\hline $\mathrm{C} \& \mathrm{FSF}$ & $50.4 \pm 1.1^{\mathrm{b}}$ & $59.6 \pm 0.1^{\mathrm{a}}$ & $72.8 \pm 1.2^{\mathrm{b}}$ & $5.1 \pm 0.7^{\mathrm{b}}$ & $22.4 \pm 2.3^{b c}$ \\
\hline \multicolumn{6}{|l|}{ Krab } \\
\hline $\mathrm{RF}$ & $66.2 \pm 0.4^{\mathrm{c}}$ & $72.9 \pm 0.3^{b}$ & $82.6 \pm 1.0^{\mathrm{d}}$ & $4.1 \pm 0.0^{\mathrm{ab}}$ & $16.4 \pm 0.6^{\mathrm{a}}$ \\
\hline CSF & $47.4 \pm 0.8^{\mathrm{a}}$ & $58.9 \pm 0.2^{\mathrm{a}}$ & $73.3 \pm 0.5^{\mathrm{b}}$ & $3.3 \pm 0.1^{\mathrm{a}}$ & $25.9 \pm 0.4^{\mathrm{cc}}$ \\
\hline C\&FSF & $49.9 \pm 0.2^{\mathrm{b}}$ & $59.3 \pm 0.4^{\mathrm{a}}$ & $70.5 \pm 0.8^{\mathrm{a}}$ & $4.3 \pm 0.6^{\mathrm{ab}}$ & $20.6 \pm 0.6^{\mathrm{b}}$ \\
\hline
\end{tabular}

Data with the same superscript alphabets in columns are not significantly different $(p<0.05)$

Values are mean $\pm \mathrm{SD}, \mathrm{n}=2$

$R F$ Raw flour, $C S F$ cooked seed flour, $C \& F S F$ cooked \& frozen seed flour respectively. According to literature data, starch gelatinization $\Delta \mathrm{H}$ values are affected by seed species, e.g. $\Delta \mathrm{H}$ values were reported to range from 4.5 to $4.8 \mathrm{~J} / \mathrm{g}$ in flour from pea seeds [33], but were shown to be significantly lower in flour from bean seeds, i.e. 2.4-3.2 J/g [13]. It may be concluded that the values obtained in our study in starch gelatinization characteristics are closer to these of pea seeds.

Temperatures of transition in CSF were significantly lower $(\mathrm{p}<0.05)$ compared to RF. $\mathrm{T}_{\mathrm{o}}$ was lower by almost $20{ }^{\circ} \mathrm{C}$, whereas in the case of $\mathrm{T}_{\mathrm{p}}$ and $\mathrm{T}_{\mathrm{c}}$ these differences were smaller, which made the range of transition temperatures in CSF to be significantly wider than in raw flours. The lower $\mathrm{T}_{\mathrm{o}}$ value may be due to starch gelatinization during cooking. The C\&FSF had also lower values of transition temperatures than the native flours, however an increase was found in $\mathrm{T}_{\mathrm{o}}$ and a decrease in $\mathrm{T}_{\mathrm{c}}$ compared to CSF. This, in turn, resulted in a narrower range of transition temperatures of C\&FSF compared to CSF. The processing affected also $\Delta \mathrm{H}$-in flours from cooked seeds (CSF) its value was lower than that in raw flour (RF), but in C\&FSF it was at the same level. Ovando-Martinez et al. [13] and Etanayake et al. [35] observed a significant decrease in $\Delta \mathrm{H}$ values after cooking seeds, i.e. below $1 \mathrm{~J} / \mathrm{g}$. The $\Delta \mathrm{H}$ decrease after heat treatment is used to calculate the extent of starch gelatinization [35]. In our study, the $\Delta \mathrm{H}$ value decreased insignificantly, probably as a result of starch retrogradation during seed drying after heat treatment. Analyses of starch retrogradation in bean flours conducted with the DSC method by Ovando-Martinez et al. [13] demonstrated that the values of $\mathrm{T}_{\mathrm{o}}$ and $\mathrm{T}_{\mathrm{p}}$ after this process were similar to these assayed in cooked seeds, however $\mathrm{T}_{\mathrm{c}}$ was higher. As a result of these phenomena, the range of transition temperatures was considerably wider and similar to that obtained in our study for CSF and C\&FSF. In addition, the $\Delta \mathrm{H}$ values determined by these authors after retrogradation were higher than those in cooked seeds and similar to our results, which may confirm the speculations about retrogradation of starch in flours from cooked seeds of grass pea. The higher $\Delta \mathrm{H}$ value in C\&FSF may indicate that starch retrogradation was more intensive in these flours.

\section{Swelling power (SP) and amylose leaching (AML) of raw and processed flour}

The swelling power of flours was determined in a temperature range from 60 to $90{ }^{\circ} \mathrm{C}$ (Table 3 ). In complex systems like flour, the SP value is determined not only by the content and structure of starch but also by the presence of proteins, as residues of polar amino acids show high affinity to water. In our study, the SP of flours was little affected by the variety of seeds they were made of. In RF, a similar increase was observed in the swelling power of both flours along with temperature increase, i.e. from 2.6 to $10.2 \mathrm{~g} / \mathrm{g}$ (Derek) and from 2.4 to $10.5 \mathrm{~g} / \mathrm{g}$ (Krab). Especially high increase in SP of raw flours occurred between $70{ }^{\circ} \mathrm{C}$ and $80{ }^{\circ} \mathrm{C}$, which is consistent with results reported for other legume starches [33]. Raw flours from both studied varieties differed - though insignificantly — also in terms of amylose leaching (AML). An especially high increase in AML value (likewise in SP value) was observed in both flours at temperatures between 70 and $80{ }^{\circ} \mathrm{C}$. The rapid increase in SP and $\mathrm{AML}$ values in this temperature range results from the total starch gelatinization.

The CSF were characterized by a significantly higher SP value at a temperature of $60{ }^{\circ} \mathrm{C}$ than the flours made of raw seeds. The lower swelling power of raw flour implies greater degree of associative forces in starch granules. The unprocessed starch swelled less at a lower temperature but its swelling was significantly greater at elevated temperature, whereas CSF contained the gelatinized starch which swelled readily at low temperature. Consequently, the SP value of flours made of cooked seeds and of cooked and frozen seeds did not decrease significantly with temperature increase, and 
Table 3 Swelling power and amylose leaching flour from raw and processed grass pea seeds

\begin{tabular}{|c|c|c|c|c|c|c|c|c|}
\hline \multirow[t]{2}{*}{ Flour } & \multicolumn{4}{|c|}{ Swelling power $(\mathrm{g} / \mathrm{g})$} & \multicolumn{4}{|c|}{ Amylose leaching $(\% \mathrm{dm})$} \\
\hline & $60^{\circ} \mathrm{C}$ & $70^{\circ} \mathrm{C}$ & $80^{\circ} \mathrm{C}$ & $90^{\circ} \mathrm{C}$ & $60{ }^{\circ} \mathrm{C}$ & $70^{\circ} \mathrm{C}$ & $80^{\circ} \mathrm{C}$ & $90^{\circ} \mathrm{C}$ \\
\hline \multicolumn{9}{|l|}{ Derek } \\
\hline $\mathrm{RF}$ & $2.6 \pm 0.0^{\mathrm{a}}$ & $5.3 \pm 0.1^{\mathrm{a}}$ & $8.8 \pm 0.1^{\mathrm{cd}}$ & $10.2 \pm 0.2^{\mathrm{c}}$ & $0.13 \pm 0.03^{\mathrm{a}}$ & $4.86 \pm 0.06^{\mathrm{d}}$ & $9.11 \pm 0.22^{\mathrm{d}}$ & $10.48 \pm 0.30^{\mathrm{e}}$ \\
\hline $\mathrm{CSF}$ & $6.0 \pm 0.2^{\mathrm{b}}$ & $7.0 \pm 0.1^{\mathrm{b}}$ & $8.1 \pm 0.7^{\mathrm{ab}}$ & $8.8 \pm 0.1^{\mathrm{b}}$ & nd & $0.09 \pm 0.00^{\mathrm{a}}$ & $0.33 \pm 0.02^{\mathrm{a}}$ & $0.67 \pm 0.02^{\mathrm{a}}$ \\
\hline C\&FSF & $6.6 \pm 0.2^{c}$ & $6.9 \pm 0.0^{\mathrm{b}}$ & $7.6 \pm 0.1^{\mathrm{a}}$ & $8.2 \pm 0.1^{\mathrm{a}}$ & nd & $0.24 \pm 0.01^{\mathrm{b}}$ & $0.59 \pm 0.04^{\mathrm{bc}}$ & $1.11 \pm 0.06^{\mathrm{bc}}$ \\
\hline \multicolumn{9}{|l|}{ Krab } \\
\hline $\mathrm{RF}$ & $2.4 \pm 0.0^{\mathrm{a}}$ & $5.3 \pm 0.2^{\mathrm{a}}$ & $9.3 \pm 0.1^{\mathrm{d}}$ & $10.5 \pm 0.1^{\mathrm{c}}$ & $0.12 \pm 0.06^{\mathrm{a}}$ & $3.41 \pm 0.19^{c}$ & $8.88 \pm 0.30^{\mathrm{d}}$ & $9.76 \pm 0.14^{\mathrm{d}}$ \\
\hline $\mathrm{CSF}$ & $6.5 \pm 0.1^{\mathrm{c}}$ & $7.6 \pm 0.2^{\mathrm{c}}$ & $8.5 \pm 0.2^{\mathrm{bc}}$ & $8.7 \pm 0.2^{\mathrm{b}}$ & nd & $0.08 \pm 0.00^{\mathrm{a}}$ & $0.35 \pm 0.03^{\mathrm{a}}$ & $0.87 \pm 0.08^{\mathrm{ab}}$ \\
\hline C\&FSF & $7.0 \pm 0.1^{\mathrm{d}}$ & $7.1 \pm 0.1^{\mathrm{b}}$ & $7.8 \pm 0.0^{\mathrm{a}}$ & $8.2 \pm 0.0^{\mathrm{a}}$ & $0.17 \pm 0.01^{\mathrm{a}}$ & $0.35 \pm 0.01^{\mathrm{b}}$ & $0.76 \pm 0.01^{\mathrm{c}}$ & $1.32 \pm 0.05^{\mathrm{c}}$ \\
\hline
\end{tabular}

Data with the same superscript alphabets in columns are not significantly different $(\mathrm{p}<0.05)$

Values are mean $\pm \mathrm{SD}, \mathrm{n}=3$, nd- no detected

$R F$ Raw flour, $C S F$ cooked seed flour, $C \& F S F$ cooked \& frozen seed flour

ultimately it was lower by ca. 14-20\% at a temperature of $90{ }^{\circ} \mathrm{C}$ than in raw flours. Similar results were obtained by Dharmaraj et al. [36] in their study on heat-treated finger millet.

Furthermore, the CSF showed significantly lower AML values compared to RF at each analyzed temperature. The significant difference in AML values between these flours may confirm that the process of starch retrogradation did proceed and that it caused the re-formation of starch crystallites characterized by higher thermal stability and lower solubility. In turn, the observed small dissolution of amylose from processed flours may result from incomplete gelatinization of some small part of starch entrapped in cells. During AML analyses, temperature increase during the heating of fine-grain flours may induce the gelatinization of starch which was not pasted while the seeds were cooked. This caused an insignificant increase in SP and AML values.

\section{Effect of processing on starch digestibility}

Table 4 presents parameters of starch digestibility in raw flours, in flours after heat treatment, and in flours made of seeds that had been earlier subjected to analogous processes and dried. Contents of rapidly-digestible starch (RDS) and slowly-digestible starch (SDS) in RF are consistent with literature data concerning flours from various legume seeds and accounting for $0-17.6 \%$ and $15.5-26.5 \%$, respectively $[13,14,37]$. Also the content of resistant starch (RS) in flour from grass pea seeds fitted the wide range reported in literature, i.e. $3.1-36 \%[13,14,33]$.

The cooking of flour caused a rapid increase in RDS content (by over 220\%) and a decrease in SDS content to the level of $0.6-1.1 \%$. Worthy of special attention is the low content of SDS, because-as indicated by literature data-legume seeds are one of its main sources in man's diet. A fine example in this case may be analyses of in vitro
Table 4 Starch fractions of flour from processed legume seeds determined by in vitro starch digestion $(\mathrm{g} / 100 \mathrm{~g} \mathrm{dm})$ and $\mathrm{pGI}$

\begin{tabular}{llllll}
\hline Variety & Sample & RDS & SDS & RS & pGI \\
\hline Derek & RF & $14.4 \pm 0.4^{\mathrm{b}}$ & $21.7 \pm 1.6^{\mathrm{f}}$ & $13.5 \pm 1.4^{\mathrm{c}}$ & $64.9 \pm 2.7^{\mathrm{b}}$ \\
& CF & $46.6 \pm 0.4^{\mathrm{g}}$ & $0.6 \pm 0.4^{\mathrm{a}}$ & $2.5 \pm 0.0^{\mathrm{a}}$ & $95.7 \pm 0.3^{\mathrm{f}}$ \\
& C\&FF & $42.6 \pm 0.8^{\mathrm{e}}$ & $2.6 \pm 0.4^{\mathrm{b}}$ & $4.5 \pm 0.4^{\mathrm{b}}$ & $91.3 \pm 0.6^{\mathrm{e}}$ \\
& CSF & $41.2 \pm 0.4^{\mathrm{d}}$ & $4.8 \pm 0.4^{\mathrm{c}}$ & $12.5 \pm 0.0^{\mathrm{c}}$ & $78.1 \pm 0.1^{\mathrm{cd}}$ \\
Krab & C\&FSF & $39.1 \pm 0.9^{\mathrm{c}}$ & $6.5 \pm 0.8^{\mathrm{d}}$ & $13.2 \pm 0.1^{\mathrm{c}}$ & $77.2 \pm 1.0^{\mathrm{cd}}$ \\
& RF & $12.5 \pm 0.5^{\mathrm{a}}$ & $19.7 \pm 0.1^{\mathrm{e}}$ & $17.7 \pm 0.6^{\mathrm{e}}$ & $57.1 \pm 0.1^{\mathrm{a}}$ \\
& CF & $44.3 \pm 0.4^{\mathrm{f}}$ & $1.1 \pm 0.4^{\mathrm{a}}$ & $4.6 \pm 0.2^{\mathrm{b}}$ & $92.5 \pm 0.1^{\mathrm{e}}$ \\
& C\&FF & $42.8 \pm 0.4^{\mathrm{e}}$ & $2.6 \pm 0.6^{\mathrm{b}}$ & $4.5 \pm 0.8^{\mathrm{b}}$ & $90.9 \pm 2.1^{\mathrm{e}}$ \\
& CSF & $42.3 \pm 0.2^{\mathrm{e}}$ & $2.8 \pm 0.6^{\mathrm{b}}$ & $12.7 \pm 0.4^{\mathrm{c}}$ & $78.8 \pm 0.3^{\mathrm{d}}$ \\
& C\&FSF & $39.7 \pm 1.0^{\mathrm{c}}$ & $4.4 \pm 0.1^{\mathrm{c}}$ & $14.8 \pm 0.9^{\mathrm{d}}$ & $75.6 \pm 2.0^{\mathrm{c}}$ \\
\hline
\end{tabular}

Data with the same superscript alphabets in the columns are not significantly different $(\mathrm{p}<0.05)$

Values are mean $\pm \mathrm{SD}, \mathrm{n}=3$

$R D S$ Rapidly digestible starch, $S D S$ slowly digestible starch, $R S$ resistant starch, $p G I$ predicted glycemic index, $R F$ raw flour, $C S F$ cooked seed flour, $C \& F S F$ cooked $\&$ frozen seed flour, $C F$ cooked flour, $C \& F F$ cooked \& frozen flour

digestibility of legume seeds conducted immediately after cooking, in which the content of SDS was significantly higher and ranged from 9.6 to $45.2 \%$ [38]. The flours from cooked seeds contained more SDS compared to the cooked flours, i.e. 2.8\% (Krab) and 4.8\% (Derek). Obviously, these values are also lower than the aforementioned literature data concerning SDS content assayed immediately after cooking seeds, but similar to the value reported for flours made of cooked seeds of other legume species [14, 37].

The increase in digestibility of seeds and flours after heat-treatment in the aqueous environment depends on the effectiveness of amylose inhibitor inactivation, denaturation degree of proteins forming the coat around starch granules, and removal of other substances affecting digestibility, but 
most of all on the degree of starch gelatinization. Because a strong correlation has already been confirmed between starch gelatinization degree and maximum glucose concentration in blood assayed in vivo and the postprandial area under the curve (AUC) [39].

Flour cooking caused also a significant decrease in RS content to the value of 2.5 and $4.6 \%$. Its content determined in $\mathrm{CF}$ fits the range reported in freshly-cooked legume seeds, i.e. $2.2-10.3 \%$ [38, 40]. The low content of resistant starch in CF was, probably, due to practically complete gelatinization of starch which caused a radical decrease in RS 2 content, whereas the period of cooling after cooking (30 $\mathrm{min}$ ) before the analysis had a little effect on starch retrogradation. Sparse studies addressing cooked flours indicate their RS content to be usually significantly lower than in cooked seeds (even three times) and to reach, e.g. 1.0-1.5\% in cooked flour from bean seeds [40, 41]. It may, therefore, be concluded that cooked flour from grass pea contains significantly more RS than flour from other seeds.

Compared to $\mathrm{CF}$, a higher content of resistant starch reaching ca. $12.5 \%$ was found in CSF. Literature works most often compare starch digestibility among freshly cooked seeds or cooked and dried seeds than among processed seeds and flours. A higher RS content after drying the cooked seeds and their disintegration compared to freshly cooked seeds and sterilized seeds was observed by e.g. Osorio-Diaz et al. $[12,42]$. As demonstrated by the authors, these differences were due to starch retrogradation during drying of seeds, which was confirmed in this study by the determined content of retrograded starch. Also results of analyses of thermal properties of flours conducted in our study, especially the high $\Delta \mathrm{H}$ value in CSF, point to retrogradation of starch during drying. Worthy of notice is the fact that RS content in flours made of cooked seeds of other species (pea, bean, lentil) was lower and ranged from 4.0 to $8.3 \%$ [14, 34], which may indicate a greater tendency of grass pea starch for retrogradation.

The storage of flour after cooking and freezing $\left(-18{ }^{\circ} \mathrm{C}\right.$, 21 days) caused a decrease in RDS content and a small increase in SDS content. The RS content increased only in C\&FF from seeds of Derek var. (by 80\%) compared to CF. In turn, flours made of seeds of both varieties (Derek and $\mathrm{Krab}$ ) that were cooked and stored after freezing had higher contents of SDS and RS compared to CSF, i.e. by 35 and $57 \%$ and by 6 and $16 \%$, respectively. Previous study based on flours from different legume species produced from seeds that were cooked, stored in the frozen state $\left(-18{ }^{\circ} \mathrm{C}, 21\right.$ days) and dried, demonstrated an increase in RS content by $60-160 \%$ compared to the flours from non-stored seeds [14]. It needs to be emphasized, however, that RS content in C\&FSF from grass pea was significantly higher compared to other legume seeds reported in the aforementioned research.

In our study, starch hydrolysis was monitored not only after 20 and $120 \mathrm{~min}$, but also after 10, 30, 60, 90, and $180 \mathrm{~min}$, which enabled plotting hydrolysis curves (Fig. 1) that were used to compute the predicted glycemic index (pGI) (Table 4). The pGI of raw flours from grass pea was higher, i.e. 64.9 (Derek) and 57.1 (Krab), compared to literature data reported for various legume flours, i.e. 44.4-56.1 [33].

Figure 1 depicts a rapid increase in the content of digested starch in $\mathrm{CF}$, which was followed by a decreased rate of starch digestion. The initial increase in starch digestion rate was also observed in CSF, but it was smaller
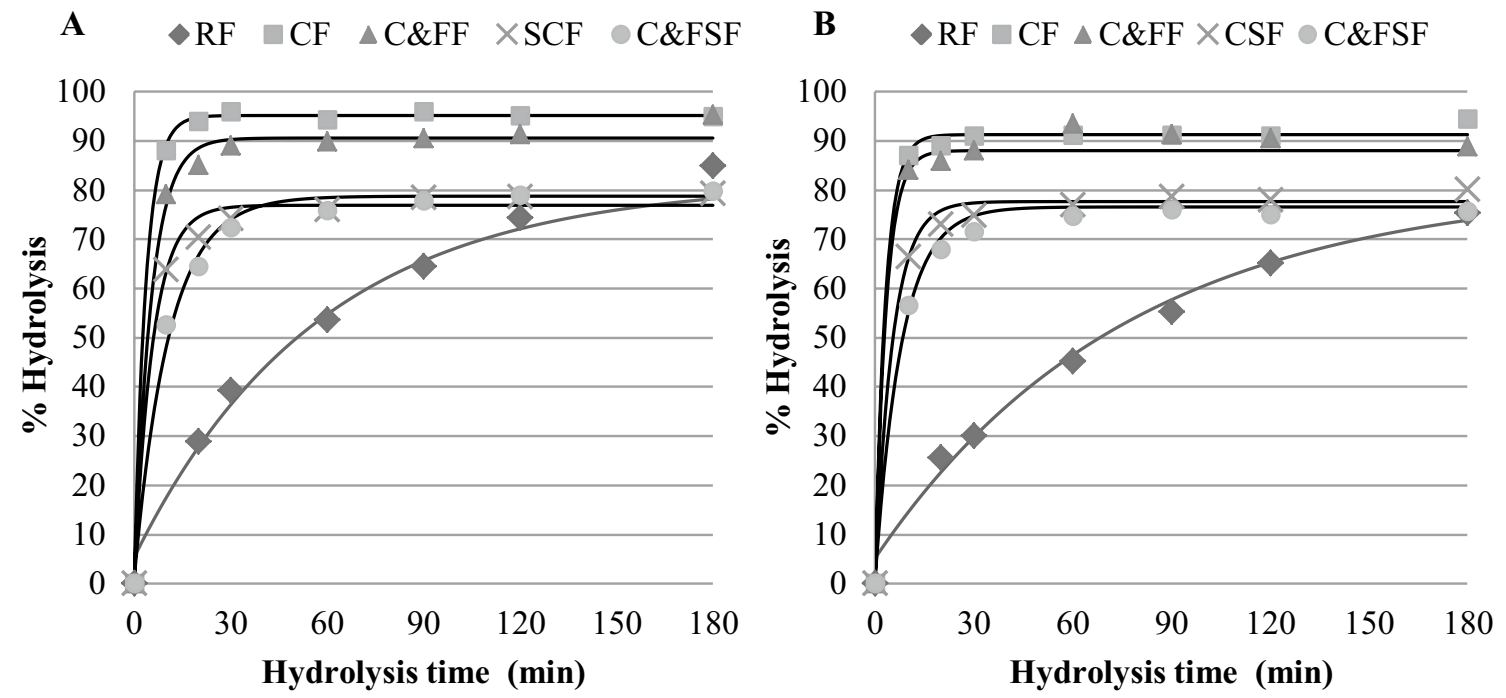

Fig. 1 In vitro starch hydrolysis curves in flour: raw (RF), cooked (CF), cooked \& frozen (C\&FF), from cooked seed (CSF) and from cooked \& frozen seed (SCF\&F) grass pea v. Derek (a) \& Krab (b) 
than in CF. These differences in starch digestion rate were reflected in pGI value (Table 4 ), which was very high in cooked flours and reached 95.7 (Derek) and 92.5 (Krab). In the case of CSF, the pGI value was significantly lower and reached ca. 78. Legume seeds are classified as food of a low GI (determined in vivo). It may be ranging between 14 and 76 as it was shown in studies collected by FosterPowell et al. [3] concerning variously prepared legumes. In the light of this data, the pGI values obtained in our study - especially for $\mathrm{CF}$ - are very high, also compared to the values determined in vitro. The conditions and extent of seed processing, especially type of heat treatment applied seem, to be of key significance in this case. Results of analyses of starch digestibility in seeds and flours from cooked and dried seeds reported in literature point to a significant effect of seeds disintegration and/or drying on pGI value. This was confirmed by Osorio-Diaz et al. [12], who demonstrated that only $20 \%$ of starch were digested after 20-min hydrolysis with $\alpha$-amylase in sterilized bean seeds, and that starch digestion in flours made of these seeds ranged from 60 to $80 \%$ depending on variety. Also Granfeldt et al. [28] manufactured food products from flour made of processed seeds, and reported their pGI to range from 57 to 60 . It needs to be emphasized, however, that in their study the degree of disintegration was not high (below $1 \mathrm{~mm}$ ) and these authors regarded their flours as containing "starch entrapped in cells".

It is difficult to find data regarding the pGI of cooked flours from legume seeds with a significant degree of disintegration, like that in our study. During heat treatment of seeds, seed hull may inhibit starch gelatinization as it constitutes a physical barrier which prevents water absorption by starch granules. In addition, apart from serving as barrier against enzymes, the intact cell walls impair penetration of water, which results in lesser starch gelatinization. This is confirmed by SP and AML values obtained in our study which indicate incomplete gelatinization of starch in cooked seeds. The cooking of disintegrated seeds ensures complete gelatinization of starch and, additionally, increases starch availability to enzymes. This is confirmed by findings reported by Würsch et al. [43], who compared starch digestibility in seeds and cooked flour (disintegration below $0.3 \mathrm{~mm}$ ). Digestibility of different seeds after $1 \mathrm{~h}$ of digestion ranged from 14 to $52 \%$, whereas that of flour ranged from 88 to $99 \%$. Similar conclusions may be drawn from two works of Vargas-Torres and al. [40, 41], who analyzed digestibility of seeds of the same bean varieties, but cooked as a whole or disintegrated before cooking. After 90-min digestion, starch digestibility reached $10-25 \%$ in seeds and $75-95 \%$ in flours. Results of the aforementioned investigations allow concluding that the high pGI values of cooked flours determined in our study were mainly affected by a high degree of disintegration, a low concentration of flour in the cooked suspension, and a relatively long period of cooking (30 min).

\section{Conclusions}

Cooking of seeds before flour production caused losses of mineral compounds, polyphenols, and lipids compared to the raw flours. These flours were also characterized by lowered temperatures and enthalpy of transitions due to starch gelatinization during cooking. However, the relatively high value of enthalpy is indicative of starch retrogradation during drying. Analyses of swelling power and amylose leaching in these flours demonstrated that only small part of starch was subject to gelatinization during the cooking of seeds. Changes observed in properties of flours made of cooked seeds, which resulted from starch retrogradation and incomplete starch gelatinization during cooking, were also reflected in starch digestibility in these flours. Compared to flour cooked after seed disintegration, the rate of hydrolysis of flours made of cooked seeds was significantly lower and, in the effect, significantly lower was also their pGI. The high rate of starch hydrolysis in cooked flour and, resultantly, its high pGI value were strongly affected by its disintegration before cooking which caused damage to cell walls that enabled complete gelatinization of starch during cooking and greater availability of starch to digestive enzymes. In turn, some part of starch remained non-pasted during cooking in the flours made of cooked seeds, whereas the pasted part was retrograded. This resulted in slower starch hydrolysis in these flours, their lower pGI, and a significantly higher content of their resistant starch than in flours cooked after disintegration. Worthy of notice is also the high content of resistant starch in both cooked flours and flours from cooked seeds of grass pea compared to seeds of other species (pea, bean, lentil), which may indicate a greater tendency of grass pea starch for retrogradation.

Acknowledgements This work was supported by the Ministry of Science and Higher Education (Project No. N N312 114238) and cofinanced by a statutory activity subsidy from the Ministry of Science and Higher Education (Poland) for the Faculty of Food Sciences of Warsaw University of Life Sciences.

Open Access This article is distributed under the terms of the Creative Commons Attribution 4.0 International License (http://creativeco mmons.org/licenses/by/4.0/), which permits unrestricted use, distribution, and reproduction in any medium, provided you give appropriate credit to the original author(s) and the source, provide a link to the Creative Commons license, and indicate if changes were made. 


\section{References}

1. M.C. Vaz Patto, R. Amarowicz, A.N. Aryee, J.I. Boye, H.J. Chung, M.A. Martín-Cabrejas, C. Domoney, Crit. Rev. Plant Sci. 34, 105-143 (2015)

2. F. Giusti, G. Caprioli, M. Ricciutelli, S. Vittori, G. Sagratini, Food Chem. 221, 689-697 (2017)

3. K. Foster-Powell, S.H. Holt, J.C. Brand-Miller, Am. J. Clin. Nutr. 76, 5-56 (2002)

4. X. Sánchez-Chino, C. Jiménez-Martínez, G. Dávila-Ortiz, I. Álvarez-González, E. Madrigal-Bujaidar, Nutr. Cancer 67, 401-410 (2015)

5. FAOSTAT (2009). ProdSTAT: Crops. FAO Statistical Databases (FAOSTAT). http://faostat.fao.org/. Accessed June 2018

6. R. Hoover, Y. Zhou, Carbohydr. Polym. 54, 401-417 (2003)

7. H.N. Englyst, S.M. Kingman, J.H. Cummings, Eur. J. Clin. Nutr. 46, 33-50 (1992)

8. P. Raigond, R. Ezekiel, B. Raigond, J. Sci. Food Agric. 95, 1968$1978(2015)$

9. I. Goni, C. Valenitn-Gamazo, Food Chem. 81, 511-515 (2003)

10. C.P. Marinangeli, A.N. Kassis, P.J. Jones, J. Food Sci. 74, S385S389 (2009)

11. J.A. Gallegos-Infante, L.A. Bello-Perez, N.E. Rocha-Guzman, R.F. Gonzalez-Laredo, M. Avila-Ontiveros, J. Food Sci. 75, 151-156 (2010)

12. P. Osorio-Diaz, L.A. Bello-Perez, E. Agama-Acevedo, A. VargasTorres, J. Tovar, A. Paderes-Lopez, Food Chem. 78, 333-337 (2002)

13. M. Ovando-Martínez, P. Osorio-Díaz, K. Whitney, L.A. BelloPérez, S. Simsek, Food Chem 129, 358-365 (2011)

14. M. Piecyk, R. Wołosiak, B. Drużyńska, E. Worobiej, Food Chem. 135, 1057-1064 (2012)

15. M. Kaur, K.S. Sandhu, R. Ahlawat, S. Sharma, J. Food Sci. Technol. 52, 1642-1648 (2015)

16. Z.H. Lu, E. Donner, R. Tsao, D.D. Ramdath, Q. Liu, Int. J. Food Sci. Technol. 53(3), 735-746 (2018)

17. E.R. Grela, W. Rybiński, R. Klebaniuk, J. Matras, Genet. Resour. Crop Evol. 57(5), 693-701 (2010)

18. A.R. Piergiovanni, F. Lupo, M. Zaccardelli, J. Sci. Food Agric. 91, 122-129 (2011)

19. E.R. Grela, S.K. Jensen, K. Jakobsen, J. Sci. Food Agric. 79(15), 2075-2078 (1999)

20. V. Padmajaprasad, M. Kaladhar, R.V. Bhat, Food Chem. 59, 77-80 (1997)

21. M. Piecyk, B. Drużyńska, A. Ołtarzewska, R. Wołosiak, E. Worobiej, E. Ostrowska-Ligęza, Int. J. Biol. Macromol. 118, 2013$2120(2018)$
22. AOAC. Association of Official Analytical Chemists, Official Methods of Analysis of AOAC, 15th ed., Arlington, VA (1990)

23. AOCS, American Oil Chemists' Society (AOCS), 5th edn. (AOCS Press, Champaign, USA, 1998)

24. V.L. Singleton, J.A. Rossi, Am. J. Enol. Vitic. 16, 144-158 (1965)

25. P.C. Williams, F.D. Kuzina, I. Hlynka, Cereal Chem. 47, 411-420 (1970)

26. H.W. Leach, L.D. Mccowen, T.J. Schoch, Cereal Chem. 36, 534 537 (1959)

27. H.-J. Chung, Q. Liu, R. Hoover, Carbohydr. Polym. 75, 436-447 (2009)

28. Y. Granfeldt, I. Björck, A. Drews, J. Tovar, Eur. J. Clin. Nutr. 46, 649-660 (1992)

29. I. Goni, A. Garcia-Alonso, F. Saura-Calixto, Nutr. Res. 17, H151H156 (1997)

30. E.R. Grela, W. Rybiński, S. Sobolewska, Problemy Higieny i Epidemiologii 92, 866-868 (2011)

31. N. Wang, D.W. Hatcher, R.T. Tyler, R. Toews, E.J. Gawalko, Food Res. Int. 43, 589-594 (2010)

32. R. Wołosiak, E. Worobiej, M. Piecyk, B. Drużyńska, D. Nowak, P.P. Lewicki, Food Res. Int. 45, 29-37 (2010)

33. H.-J. Chung, Q. Liu, R. Hoover, T.D. Warkentin, B. Vandenberg, Food Chem. 111, 316-321 (2008)

34. M. Piecyk, B. Drużyńska, E. Worobiej, R. Wołosiak, E. Ostrowska-Ligęza, Food Res. Int. 50, 428-437 (2013)

35. S. Ekanayake, B.M. Nair, N.G. Asp, E.R. Jansz, Starch-Stärke 58, 215-222 (2006)

36. U. Dharmaraj, M.S. Meera, S.Y. Reddy, N.G. Malleshi, J. Food Sci. Technol. 52, 1361-1371 (2015)

37. E. Marconi, S. Ruggeri, M. Cappelloni, D. Leonardi, E. Caenoval, J. Agric. Food Chem. 48, 5986-5994 (2000)

38. R. Eyaru, A.K. Shrestha, J. Arcot, Food Res. Int. 42, 956-962 (2009)

39. J. Parada, J.M. Aguilera, Food Res. Int. 45, 238-243 (2012)

40. A. Vargas-Torres, P. Osorio-Díaz, J.J. Islas-Hernández, J. Tovar, O. Paredes-López, L.A. Bello-Pérez, J. Food Compost. Anal. 17, 605-612 (2004)

41. A. Vargas-Torres, P. Osorio-Diaz, J. Tovar, O. Paredes-Lopez, J. Ruales, L.A. Bello-Perez, Starch 56, 74-76 (2004)

42. P. Osorio-Diaz, L.A. Bello-Perez, S.G. Sayago-Ayerdi, M.P. Reyes-Benitez, J. Tovar, O. Paredes-Lopez, J. Sci. Food Agric. 83, 1283-1288 (2003)

43. P. Würsch, S. Del Vedovo, B. Koellreutter, Am. J. Clin. Nutr. 43, 25-29 (1986) 